\title{
The Anticancer Activity of the Marine Sponge Aaptos suberitoides to Protein Profile of Fibrosarcoma Mice (Mus musculus)
}

\author{
Noor Nailis Sa'adah ${ }^{1}$, Awik Puji Dyah Nurhayati ${ }^{1}$, and Maya Shovitri ${ }^{1}$
}

\begin{abstract}
The study was aimed to evaluating anticancer activity of A. suberitoides on protein profile of blood plasma of fibrosarcoma mice (M. musculus). Mice were induced by Benzo(a)pyrene on the subcutaneous tissue intravenously with a concentration of 0,3 gram/0,2 oleum olivarum/day for 2 weeks. Mice were treated with ethanolic extract of A. suberitoides every day for two weeks. There were six groups. The first group (I) was control. Group II, mice were induced by $\mathrm{CMCNa}$, Group III mice were treated by Cyclophosphamide. Group IV, V and VI mice were treated by ethanolic extract of A. suberitoides with 500, 1000 and $1500 \mathrm{mg} /$ weight. Mice blood were taken at week fifteen. Protein profile of mice was measured by electrophoresis SDS-PAGE. The protein profile indicated that the mice were induced benzo(a)pyrene (Group II, III, IV, V and VI) have a new protein band (41 kDa). The protein band not presented in control (Group I). The protein band ( $7 \mathrm{kDa}$ ) was in Groups I and II, but it not presented in Groups III, IV, V and VI. The most interesting protein band was $115 \mathrm{kDa}$, which presented only in Groups II, III and IV. The research showed that the sponge extract with concentration of 1000 and $1500 \mathrm{mg} /$ weight repressed the expression of protein $115 \mathrm{kDa}$.
\end{abstract}

Keywords - marine sponge A. suberitoides, anticancer, fibrosarcoma, protein profile.

Abstrak-Penelitian ini bertujuan untuk mengetahui aktivitas antikanker dari A. suberitoides terhadap profil protein plasma darah mencit fibrosarkoma (M. musculus). Mencit diinjeksi senyawa benzo(a)piren pada jaringan subkutan secara intravena dengan konsentrasi 0,3 gram/0,2 oleum olivarum/hari selama 2 minggu. Mencit diterapi dengan ekstrak etanol A. suberitoides setiap hari selama 2 minggu. Mencit dikelompokkan menjadi 6 grup. Kelompok I adalah kontrol; Kelompok II mencit diinjeksi CMCNa; Kelompok III mencit diterapi dengan Cyclophosphamide. Kelompok IV, V, dan VI mencit diterapi dengan ekstrak etanol A. suberitoides dengan konsentrasi 500, 1000, $1500 \mathrm{mg} / \mathrm{kg} \mathrm{BB}$. Pada minggu ke-15 dilakukan pengambilan plasma darah mencit. Profil protein mencit dianalisis menggunakan metode SDSPAGE. Profil protein menunjukkan bahwa mencit yang diinjeksi benzo(a)pyrene (Kelompok II, III, IV, V dan VI) memiliki protein baru (4I kDa). Pita protein ini tidak muncul pada kontrol (Kelompok I). Pita protein 7 kDa terdapat pada Kelompok I dan II, tetapi tidak muncul pada Kelompok III, IV, V, dan VI. Pita protein yang paling penting adalah protein $115 \mathrm{kDa}$, yang hanya muncul pada Kelompok II, III, dan IV. Penelitian ini menunjukkan bahwa ekstrak spons dengan konsentrasi 1000 dan 1500 mg/kg BB dapat menekan ekspresi protein 115 kDa.

Kata Kunci-spons laut A. suberitoides, antikanker, fibrosarkoma, profil protein.

\section{INTRODUCTION}

$I^{\prime}$ ndonesia is an island country that rich in natural resources, including marine sponges. Marine sponges have bioactive compounds which potential as antibacterial, antiviral, antifungal and anticancer. The bioactive compounds including alkaloids, aceto-genin, peptides, saponins, terpenoids, sterols, etc. [1].

Aaptos suberitoides is one species of marine sponge that produce alkaloid compound, aaptamin (benzo 1,6naphthyridin) [2]. Aaptamin compound potential as an anticancer [3], which works by apoptosis [4] and antioxidants [5]. Apoptosis is the mechanism of cell death, so that proliferation of cells undergoing DNA damage can be prevented [6]. On the mechanism of antioxidant, aaptamin inhibit action of free radicals to bind to an important molecule in the body, DNA [7].

Cancer is caused by carcinogenic compounds. Benzo (a) pyrene is one of precarcinogenic compounds. Precarcinogen benzo(a)pyrene is converted to an active carcinogen by cytochrome P-450. Active carcinogens highly reactive and attack easily to nucleophilic groups in DNA, RNA and proteins, that cause mutations [8].

${ }^{1}$ Noor Nailis Sa'adah, Awik Puji Dyah Nurhayati, and Maya Shovitri are with Departement of Biology, Faculty of Mathematic and Natural Science, Institut Teknologi Sepuluh Nopember, Surabaya, 60111, Indonesia. E-mail: n.nailis.saadFaculty ah@gmail.com; awiknurhayati@gmail.com; maya@bio.its.ac.id
P53 gene encodes a p53 protein which functions as a tumor suppressor protein. Carcinogenesis begins with damage or mutation of p53 gene. Mutated p53 gene synthesize mutant p53 protein. For cancer patient, mutant p53 protein was accumulated in tumor tissues and in the blood serum. Mutant p53 protein in serum of tumor patients increase with danger levels of disease, so it can be used as an early biomarker of tumor [9].

The activity of anticancer compounds of marine sponge A. suberitoides rude extract tested in cancer mice (Mus musculus), by observing blood plasma protein profile of mice (M. musculus). Observations protein profiles can be done by western blot method. Correa, et al [10] using Western blot method for observing protein profiles of cancer. Another method that can be used to study protein profiles is sodium dodecyl sulfate-polyacrylamide gel electrophoresis (SDS-PAGE) method. SDS-PAGE method is relatively easy and the results are quite good [11].

\section{METHODS}

\section{A. Time and Location Research}

The research done in October 2009 - March 2010. Sponge samples were taken at Pasir Putih, Situbondo. Extraction of A. suberitoides, inducing carcinogenic and delivery of anticancer agents to mice (M. musculus) was conducted at the Pharmacognosy Laboratory, Faculty of Pharmacy, Airlangga University, Surabaya. Analysis of 
protein profile of cancer mice (M. musculus) which treated with extracts of $A$. suberitoides was done at Laboratorium Penelitian dan Pengujian Terpadu (LPPT) Unit III UGM.

\section{B. Materials}

The materials are feed Comfeed ${ }^{\circledR}$, male mice $(M$. musculus) strain B Albino clone (BALB/c) 3 months old, benzo(a)pyrene, oleum olivarum, distilled water, ether, anticoagulant ethylenediamine-tetraacetic acid (EDTA) and $A$. suberitoides extract. In addition, materials for the SDS-PAGE are lower gel buffer, upper gel buffer, loading buffer, coomassie blue, destainer solution, separating gels $12 \%$ and $3 \%$ stacking gels.

\section{Preparation of Animal Test}

Animal test are male mice (M. musculus) strain B Albino clone (BALB/c) 3 months old. Mice were acclimatized for 1 week and were given fed Comfeed ${ }^{\circledR}$ and distilled water.

\section{Inducing Carcinogenic Benzo(a)pyrene}

At week 2, inducing carcinogenic by injecting a solution of benzo(a)pyrene intravenously in cervical subcutaneous tissue of mice. Benzo(a)pyrene 0.3 gr dissolved in $0.2 \mathrm{ml}$ of oleum olivarum. Injection was done every two days for 2 weeks. Then, waited until cancer was presented, i.e. the appearance of a lump on cervix mice for \pm 2 months. For controls, mice $(M$. musculus) were not injected by benzo(a)pyrene.

\section{E. Testing Anticancer Activity of A. suberitoides}

Once a symptom of cancer (lump) appeared, mice were given an anticancer treatment from $A$. suberitoides extracts. It was administered orally every day for 2 weeks. A. suberitoides extract concentration was 500, 1000 , and $1500 \mathrm{mg} / \mathrm{kg}$. The dosage is based on advisability of drug dosage in humans. Mice ( $M$. musculus) were randomized into 6 groups. Each group received treatment as follows:

Group I : control group (healthy group)

Group II : cancer group

Group III : cancer group was given cancer drug cyclophosphamide $0.4 \mathrm{ml} / 0.2 \mathrm{ml}$ $\mathrm{CMCNa}$

Group IV : cancer group was treated sponge extracts with a concentration of $500 \mathrm{mg} / \mathrm{kg}$

Group V : cancer group was treated sponge extracts with a concentration of $1000 \mathrm{mg} / \mathrm{kg}$

Group VI : cancer group was treated sponge extracts with a concentration of $1500 \mathrm{mg} / \mathrm{kg}$

Taking the blood plasma of mice at week 15 or 2 weeks after anticancer therapy with A. suberitoides extract. Electrophoresis of blood plasma of mice was conducted using SDS-PAGE method.

\section{F. Proteins Profile of Blood Plasma of Mice}

\section{1) Sample Preparation}

Blood sample was taken from cardiac puncture of mice (M. musculus) with syiringe. It was put in microtubes and given anticoagulant-ethylenediamine tetraacetic acid (EDTA). Then, it was stored in ice $\left(-20^{\circ} \mathrm{C}\right)$ until process of electrophoresis.

Blood was centrifuged at $3000 \mathrm{rpm}$ for 10 minutes, then supernatant (plasma) was taken. Plasma $5 \mathrm{~mL}$ was pipetted and dissolved in $145 \mathrm{~mL}$ of distilled water $(30 \mathrm{x}$ dilution). Then it was added $50 \mathrm{~mL}$ of loading buffer. Sample was heated at $95{ }^{\circ} \mathrm{C}$ for 4 minutes.

\section{2) SDS-PAGE Method}

Protein profile of mice (M. musculus) was determined by SDS-PAGE $12 \%$ method. Six ml of $12 \%$ separator gel solution were loaded on glass plate and coated with 1 $\mathrm{ml}$ of butanol, then allowed to stand for 15 minutes in order to condense. Once solidified, butanol was removed and added stacking gel $3 \%$ on above separator gel. Comb was inserted between plate and allowed to stand for 10 minutes, after solid comb was taken.

Solid gel was put in an electrophoresis box and filled with buffer to the surface. Sample was inserted into gel wells $(10 \mathrm{~mL} /$ well $)$, then was electrophoresed with 120 $\mathrm{V}$ electrical current for 1.5-2 hours. Electrophoresis was stopped until blue color touch base gel. Gel electrophoresis was removed from device and inserted into a coomassie blue dye box and incubated for 24 hours at $42 \mathrm{rpm}$ wobble. After that, gel was transferred to a containing destainer solution to removed excess dye. Furthermore, destainer solution was removed and replaced with $10 \%$ acetic acid solution for storage gel electrophoresis. Protein bands were observed and visible protein bands were photographed directly using digital camera Nikon $\AA$.

3) Standard Curves and Analysis of Protein Bands

Molecular weight of protein sample was calculated using a standard curve $(y=a x+b)$. Standard curve was constructed by measuring distance marker bands of well. Marker was used are Prestained SDS PAGE (Biorad®, Germany) with a molecular weight of $7 \mathrm{kDa}$ to $206 \mathrm{kDa}$. Bands distance were used as ordinate ( $\mathrm{x}$ axis) and abscissa (y axis) was logaritm of marker molecular weight. Curve Fitted Line Plot was made from ordinat and abscissa value using Minitab 14.

$$
y=a x+b
$$

Description:

$\mathrm{X}=$ Bands distance from well

$\mathrm{Y}=$ logaritm of marker molecular weight

Bands of protein sample were analyzed by comparing the marker.

\section{G. Data Analysis}

Data was analyzed descriptively include presence or not of protein bands, molecular weight of protein bands and thin or thick of protein bands. Analysis of protein profile only was done on a consistent protein bands, protein bands which presented in all replications (replications running and individuals) and protein bands which have relatively the same thickness.

\section{RESULTS AND DISCUSSIONS}

\section{A. Consistency of Plasma Protein Profile of Mice with SDS-PAGE Method}

Marker was used in the method is Prestained (Biorad ${ }^{\circledR}$, Germany) containing myosin, $\beta$-galactosidase, bovine plasma albumin, ovalbumin, carbonic anhydrase, soybean trypsin inhibitor, lysozyme and aprotinin, with consecutively molecular weight are 206, 118, 97, 54, 37, 29, 17 and $7 \mathrm{kDa}$. Result of SDS-PAGE of blood plasma of mice (M. musculus) was obtained various proteins. The result of running and individual replications, there are consistent and not consistent bands of protein. 
Consistent protein bands are protein bands which present on all replicates (running and individuals replications) with relatively the same thickness. Consistent protein bands are the $\mathrm{V}(104 \mathrm{kD})$ and $\mathrm{W}(49 \mathrm{kDa})$ protein (Figure 1), while the not consistent protein band is $\mathrm{X}$ protein $(9 \mathrm{kDa})$ (Figure 1).

Consistency of presence of blood plasma protein bands is influenced by the physiological condition of individual mice, among others, feed intake or specific immune response to the pathogen. Feed were used are Par G pellet, production of Comfeed which containing carbohydrates, lipid and protein. Increasing consumption of feed cause the amount of carbohydrates, fats and proteins into the body as well increased. The excess carbohydrate will be stored as glycogen that rapidly is converted into triacylglycerols and stored in the adipose tissue. Conversion glucose into fat is a process that occurs easily on the optimal nutritional intake state [12]. Triacylglycerol is hydrolysed by lipase into fatty acids and glycerol. Free Fatty acid release into the plasma and join with plasma albumin. Free fatty acids with lower levels are found in the after eating state and would be rise about $0.5 \mu \mathrm{eq} / \mathrm{mL}$ in post-absorption state [8].

Increasing of fat in the body followed by an increase fat metabolism [12]. Fat which absorbed from food will be transported to various tissues and organs of the body to be used and stored. Transporting lipids in the blood plasma are done by combining non-polar lipid compound (triacylglycerol and cholesteryl ester) with lipid amphipathic (phospholipids and cholesterol) and proteins, form a lipoprotein [8]. The higher level of lipoproteins in blood plasma cause the protein bands that expressed are thicker.

Increasing of food consumption also increases essential amino acid entry into the body. However, the excess amino acids will not be stored in the body, but it will be break down rapidly [8] so it is not effect on plasma protein profile.

Physiological differences of mice also caused by infection that causes a specific immune response. When a pathogen invades the body of mice, each antigen activate B cells which differentiate into plasma cells and memory cells. Plasma cells make specific antibodies (immunoglobulins) that against invading pathogens. Animals were first attacked by a pathogen express IgM. Animals that have been attacked by the same pathogen, express IgG secondary immune response. The higher IgM levels in the plasma is an early sign of infection. IgM and IgG different in their molecular weight, where the $\operatorname{IgM}$ is $900 \mathrm{kDa}$ and $\operatorname{IgG}$ is $150 \mathrm{kDa}$ [8]. The difference in molecular weight causes a difference protein profile that was expressed in each individual control mice.

Therefore, analysis of protein profiles have been done on a consistent protein bands. Consistently protein bands describe the differences of protein profile which given a treatment compared with controls.

B. Analysis of Plasma Protein Profile of Mice after Treated by Carcinogenic and Anti-carcinogenic

Mice were injected benzo(a)pyrene for 2 weeks showed a cancerous lump in the neck (cervical) where injection was done (Figure 2). The cancerous lump seen in all groups except control group were not injected with benzo(a)pyrene.
Benzo(a)pyrene is a polycyclic prototypic hydrocarbon compounds. It bind to DNA that cause mutations in p53 gene, i.e. regulator gene of cell cycle [13]. Mutant p53 protein $(53 \mathrm{kDa})$ causes activation of protooncogene into oncogene. Oncogene cause the loss of control of cell growth, and causing cancer. p53 is one of the most frequently mutated genes in human cancers [8].

Differences in protein profiles that occur during pathological conditions indicate the presence of protein biomarkers. Protein biomarkers are used for diagnosis and prognosis of various of cancer and other diseases. Concentration of a particular protein can be increase or decrease during progression of disease. Different levels of protein expression in line biomarker of disease progression [14].

Results of blood plasma protein profile analysis of mice showed that group I (control) consisted of protein bands were consistently presented with sizes 7, 9, 11, 27, 34, 49, 56, 66, 82, 104, 121, 145 and $162 \mathrm{kDa}$ (Table 1). This results also showed that injection of benzo(a)pyrene effected on blood plasma protein profile of cancer mice (M. musculus). Protein $41 \mathrm{kDa}$ appeared in groups injected with benzo(a)pyrene, i.e. groups II, III, IV, V and VI. Injection of benzo(a)pyrene, giving extract of $A$. suberitoides, and cyclophosphamide caused of lose and presence of a particular protein. Protein $7 \mathrm{kDa}$ only appeared in untreated group (group I and II) and not expressed in group were treated with extracts of $A$. suberitoides and cyclophosphamide (group III, IV, V and VI). Protein $115 \mathrm{kDa}$ appeared in groups II, III and IV, while other groups (group I, V and VI) are not expressed (Figure 3) (Table 1).

Cancer cells able to metastasize primarily through the flow of lymph and blood vessels so that cellular proteins enter to bloodstream. The entry of these proteins into bloodstream cause appearance of a new protein in blood plasma and cause differences in protein profiles compared with controls.

Oncogene in cancer cells encode typical proteins which role in various physiological functions of cancer cells, they are Ras (21 kDa), c-myc (65 kDa), PRAD1 (36 $\mathrm{kDa})$ and Fes protein $(92 \mathrm{kDa})$ [8]. Although in this study, those proteins were not detected (based on molecular weight) (Figure 3). This may be caused Fes protein specific to leukemia, PRAD1 protein specific to breast and esophageal tumors, whereas the Ras protein specific to lung tumors, colon and pancreas [8]. Other proteins are expressed in cancer cells are a $7 \mathrm{kDa}$ protein which presumed function in cell proliferation [15] and $115 \mathrm{kDa}$ protein that functions in cell adhesion [16].

Yang and Page research reported that $7 \mathrm{kDa}$ protein is a membrane protein that it is expressed excessively on ovarian cancer cells. Protein $7 \mathrm{kDa}$ on plasma membrane is presumed to involve in proliferation mechanism of ovarian cancer cell so that resistant to various types of drugs (multidrug resistant) [15]. However, in this study 7 $\mathrm{kDa}$ protein was founded in healthy mice group (group I) and fibrosarcoma mice group (group II) with almost the same thickness (Figure 3). Whereas in III, IV, V and VI group were injected benzo(a)pyrene, $7 \mathrm{kDa}$ protein was not detected. There are some possible that cause the present of the proteins in this study although the continuous review both in the laboratory and literature absolutely must be done. 
The possibilities are:

1. In the control group, normal cells also perform cell proliferation and $7 \mathrm{kDa}$ protein which detected is role in the cell proliferation.

2. $7 \mathrm{kDa}$ protein was detected in fibrosarcoma mice (group II) and was not detected in group III, IV, V and VI. This may indicate that $7 \mathrm{kDa}$ protein also serves to fibrosarcoma cancer cell proliferation as reported Yang and Page [15], but not expressed due to administration of cyclophosphamide and $A$. suberitoides extracts. Cyclophosphamide including of alkylating substances which when reacting with DNA may lead to changes in structure of DNA so that function of DNA is disrupted. Disruption of DNA function is expected to reduce ability of cell proliferation. A. suberitoides extracts contain bioactive compounds, aaptamin (benzo 1,6naphthyridin) [2] and it include alkaloid groups [17] Alkaloid compounds as antimitotic have ability to bind to tubulin, i.e. a proteins that compose the microtubule, it inhibit protein polymerization into microtubules [18]. Barriers of polymerization protein were presumed to interfere cell proliferation.

Theilgaard et al. reported that $41 \mathrm{kDa}$ protein $(\alpha 1$-acid glycoprotein) is one of acute phase proteins which produced by hepatocytes cells and secreted into the plasma in response to infection or cell damage [19]. Generally, cell damage is caused by radiation, toxic chemicals, drugs, toxic bacteria, physical damage, etc. Cell damage is followed by permeability and hemodynamic adaptation, causing inflammation. It cause systemic response and improves circulation of leukocytes, especially macrophages and neutrophils [20]. Response to cell damage triggers systemic acute phase reaction which characterized by increasing of plasma protein synthesis in the liver. If injection of benzo(a)pyrene in subcutaneous continuously (5 times) cause cellular damage, it can be presumed that $41 \mathrm{kDa}$ protein was detected in this study are the same proteins as reported by Theilgaard et al. [19]. Protein $41 \mathrm{kDa}$ expressed in group which injected benzo(a)pyrene (groups II, III, IV, V and VI). In normal mice group (group I), $41 \mathrm{kDa}$ protein was not detected because it is not injected benzo(a)pyrene so there is not cell damage.

The cell surface receptor protein $(115 \mathrm{kDa})$ was found in the cell osteosarcoma (bone cancer) human. Protein $115 \mathrm{kDa}$ functions as a receptor protein on the surface of specific cells to vitronectin in process of adhesion /cell migration. Cell surface receptor protein causes cell to interact with other cells and intracellular substances, causing cell adhesion. Extracellular matrix molecules that play a role in cell adhesion, among others, are fibronectin, collagen, laminin, proteoglycans and vitronectin [16]. Cancer cells are able to metastasize from the primary tissue to other tissues where cells are grown as secondary cancer. Tumor cells penetrate Extra Cellular Matrix (ECM) of cells around by attached to ECM. This is possible because tumor cells have receptors for extracellular matrix molecules. Protein 115 $\mathrm{kDa}$ was expressed in groups II, III and IV. If it was assumed that $115 \mathrm{kDa}$ protein found on fibrosarcoma is the same as $115 \mathrm{kDa}$ protein found on osteosarcoma (bone cancer) cell, then the loss of $115 \mathrm{kDa}$ protein in group V and VI may be caused by influence of dosage of
A. suberitoides extracts. Administration of cyclophosphamide and A. suberitoides extracts with dosage $500 \mathrm{mg} / \mathrm{kg}$ have not been to cure cancer, while extract of A. suberitoides 1000 and $1500 \mathrm{mg} / \mathrm{kg}$ presumed more effective in curing cancer cells.

A. suberitoides extracts which used for therapy is not a pure extract but still a crude extract consisting of mixture of compounds in sponges; alkaloids, terpenoids and flavonoids, so that required a higher dosage. Fractions in sponges extract are not separated from one another so that alkaloid compounds still mixed. In general, pure compound have stronger biological activity with notes during purification process, active compounds are not lost or damaged [21].

\section{CONCLUSIONS}

1. There was difference of blood plasma protein profile in fibrosarcoma mice (M. musculus) which treated with $A$. suberitoides extract with concentrations of 500,1000 and $1500 \mathrm{mg} / \mathrm{kg}$.

2. Compared with controls, appeared new protein, 41 $\mathrm{kDa}$ and $115 \mathrm{kDa}$ protein. Protein7 $\mathrm{kDa}$ only appeared in untreated group (group I and II) and not expressed in group which treated with extracts of $A$. suberitoides and cyclophosphamide (group III, IV, V and VI). Protein $41 \mathrm{kDa}$ appeared in group which injected benzo(a)pyrene (group II, III, IV, V and VI). Protein $115 \mathrm{kDa}$ appeared in groups II, III and IV, while the other group (group I, V and VI) was not expressed.

\section{ACKNOWLEDGEMENTS}

The authors are grateful for the support provided by Sepuluh November Institute of Technology. In addition, the authors would like to thank Gadjah Mada University and Airlangga University for the facilities support.

\section{REFERENCES}

[1] S. Suparno, Kajian Bioaktif Spons Laut (Porifera: Demospongiae) Suatu Peluang Alternatif Pemanfaatan Ekosistem Karang Indonesia Dalam Bidang Farmasi, Bogor: IPB, 2005.

[2] A. F. Coutinho, B. Chanas, T. M. L. Souza, I. C. P. P. Frugrulhetti and R. d. A. Epifanio, "Anti HSV-1 Alkaloids from a Feeding Deterrent Marine Spongse of The Genus Aaptos," Heterocycles, vol. 57, no. 7, pp. 1265-1272, 2002.

[3] S. Aoki, D. Konga, H. Sunaa, Y. Sowab, T. Sakaib, A. Setiawan and M. Kobayashi, "Aaptamin, a Spongean Alkaloid, Activates p21 Promoter in a p53-Independent Manner," Biochemical and Biophysical Research Communications, vol. 342, no. 1, pp. 101106, 2006.

[4] A. M. S. Mayer and K. R. Gustafson, "Marine Pharmacology in 2005-2006: Antitumour and Cytotoxic Compounds," European Journal of Cancer, vol. 44, no. 16, p. 2357-2387, 2008.

[5] A. E. Makarchenko and N. K. Utkina, "Antiradical Activity of Alkaloids from Marine Sponges," in International Conference on Natural Products and Physiologically Active Substances (ICNPAS-2004), Novosibirsk, Russia, 2004.

[6] M. K. Tadjudin, "Apoptosis Pada Glioma Otak," in Symposium Apoptosis Charming to Death 2006 FK UI, Jakarta, 2006.

[7] E. Hanani, A. Munim and R. Sekarini, "Hanani, E., Mun'im, A. dan Sekarini. . "Identifikasi Senyawa Antioksidan dalamSpons Callyspongia sp dari Kepulauan Seribu," Majalah Ilmu Kefarmasian, vol. 2, no. 3, p. 127 - 133, 2005.

[8] R. K. Murray and D. K. Granner, Biokimia Harper, Jakarta: EGC, 2003

[9] A. M. Attallah, M. Abdel-Aziz, A. M. El-Sayed and A. A. Tabll, "Detection of Serum P53 Protein in Patients with Different Gastrointestinal Cancers," Cancer Detection and Prevention, vol. 27 , no. 2, p. 127-131, 2003 
[10] I. Correa, M. A. Cerbón, A. M. Salazar, J. D. Solano, A. GarcíaCarrancá and A. Quintero, "Differential p53 Protein Expression Level in Human Cancer-Derived Cell Lines After Estradiol Treatment," Archive of Medical Research, vol. 33, no. 5, pp. 455459, 2002.

[11] S. Wongsosupantio, Elektroforesis Gel Protein, Yogyakarta: UGM, 1992.

[12] S. Isdadiyanto, "Lemak Abdominal Mencit (mus musculus) Setelah Pemberian Kitin Per-oral," Jurnal Sains \& Matematika, vol. 16, no. 3, pp. 150-152, 2008.

[13] F. R. Zakaria, "Pangan dan Pencegahan Kanker," Jurnal Teknologi dan Industri Pangan, vol. 12, no. 2, pp. 171-177, 2001.

[14] S. Naz, S. Ahmad and F. Ghafoor, "Qualitative Analysis of Serum Proteins in Benign Prostatic Hyperplasia Separated By SDS-PAGE," ARPN Journal of Agricultural and Biological Science, vol. 4, no. 6, pp. 24-28, 2009.

[15] X. Yang and M. Pagé, "An Mr 7 kDa Membrane Protein Overexpressed in human multidrug-resistant ovarian cancer cell," Cancer Letters, vol. 88, no. 2, pp. 171-178, 1995.

[16] R. Pytela, M. D. Pierschbacher and E. Ruoslahti, "A 125/115-kDa Cell Surface Receptor Specific for Vitronectin Interacts with the Arginine-glycine-aspartic acid Adhesion Sequence Derived from

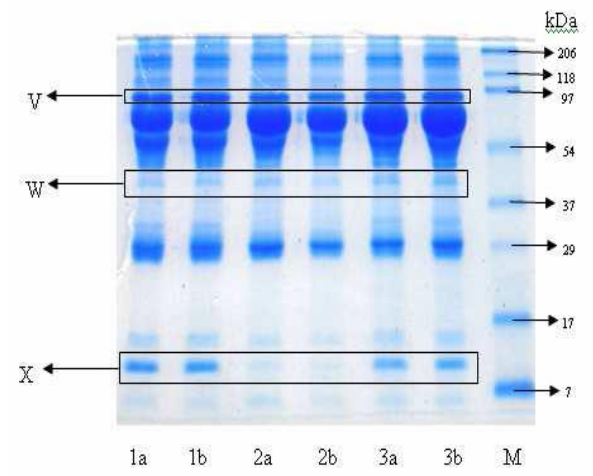

Figure 1. Blood plasma protein profile of control mice with SDSPAGE method

Description :

1,2 and $3 \quad$ : an individual replication,

$\mathrm{a}$ and $\mathrm{b} \quad \mathrm{:}$ a running replication in the same individual
Fibronectin," Proc Natl Acad Sci U S A., vol. 82, no. 17, pp. 5766-5770, 1985.

[17] T. Murniasih, "Substansi Kimia untuk Pertahanan Diri dari Hewan Laut Tak Bertulang Belakang," Oseana, vol. 30, no. 2, p. $19-27,2005$

[18] T. Murniasih and R. R. Satari, "Isolasi Substansi Bioaktif Antimikroba dari Spons Asal Pulau Pari Kepulauan Seribu," in Seminar Bioteknologi Kelautan Indonesia I, Jakarta, 1998.

[19] K. Theilgaard-Mönch, L. C. Jacobsen, T. Rasmussen, C. U. Niemann, L. Udby, R. Borup, M. Gharib, P. D. Arkwright, A. F. Gombart, J. Calafat, B. T. Porse and N. Borregaard, "Highly Glycosylated $\alpha 1$-acid Glycoprotein is Synthesized in Myelocytes, Stored in Secondary Granules, and Released by Activated Neutrophils," Journal of Leukocyte Biology, vol. 78, no. 2, pp. 462-470, 2005

[20] D. O. Slauson and B. J. Cooper, Mechanisms of Disease: A Textbook of Comparative General Pathology, Baltimore: Williams and Wilkins, 1990.

[21] M. Nursid, T. Wikanta, N. Fajarningsih and E. Marraskuranto, "Aktivitas Sitotoksik, Induksi Apoptosis dan Ekspresi Gen P 53 Fraksi Metanol Ekstrak Spons Petrosia sp. Terhadap Sel Tumor HeLa," Jurnal Pascapanen dan Bioteknologi Kelautan dan Perikanan, vol. 1, no. 2, pp. 103-110, 2006.

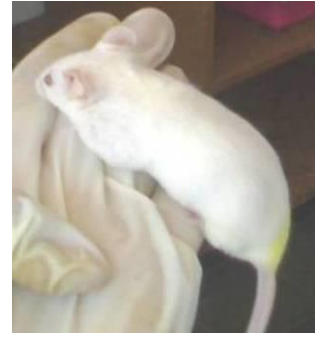

(a)

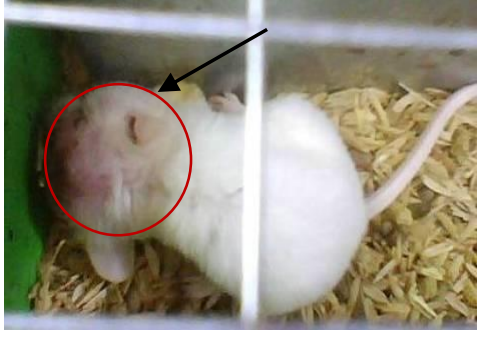

(b)
Figure 2: (a). Normal mice without the lump in the cervix (b). Cancer mice with symptoms such as a lump in the cervix

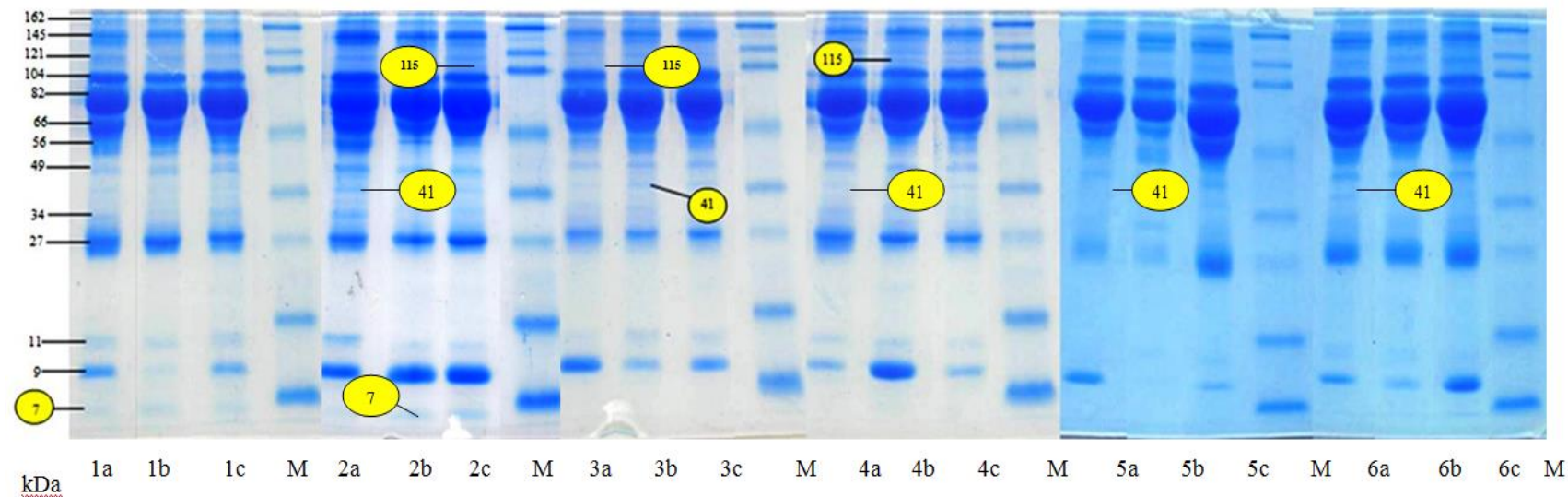

Figure 3. Blood plasma protein profile of mice with SDS-PAGE method. $\bigcirc$ : The protein be present in some group and not present in other groups after treatment with ethanolic extract of $A$. suberitoides. Those protein are 7, 41, and $115 \mathrm{kDa}$ protein 
TABLE 1.

SUMMARY OF BLOOD PLASMA PROTEIN PROFILE OF MICE WITH SDS-PAGE METHOD

\begin{tabular}{|c|c|c|c|c|c|c|c|c|c|c|c|c|c|c|c|c|c|c|}
\hline \multirow{2}{*}{$\begin{array}{c}\text { MW } \\
\text { (KDa) }\end{array}$} & \multicolumn{18}{|c|}{ Treatment group } \\
\hline & Ia & Ib & Ic & IIa & IIb & IIc & IIIa & IIIb & IIIc & IVa & IVb & IVc & Va & $\mathbf{V b}$ & Vc & VIa & VIb & VIc \\
\hline 162 & & & & & & & & & & & & & & & & & & \\
\hline 145 & & & & & & & & & & & & & & & & & & \\
\hline 121 & & & & & & & & & & & & & & & & & & \\
\hline 115 & & & & & & & & & & & & & & & & & & \\
\hline 104 & & & & & & & & & & & & & & & & & & \\
\hline 82 & & & & & & & & & & & & & & & & & & \\
\hline 66 & & & & & & & & & & & & & & & & & & \\
\hline 56 & & & & & & & & & & & & & & & & & & \\
\hline 49 & & & & & & & & & & & & & & & & & & \\
\hline 41 & & & & & & & & & & & & & & & & & & \\
\hline 34 & & & & & & & & & & & & & & & & & & \\
\hline 27 & & & & & & & & & & & & & & & & & & \\
\hline 11 & & & & & & & & & & & & & & & & & & \\
\hline 9 & & & & & & & & & & & & & & & & & & \\
\hline 7 & & & & & & & & & & & & & & & & & & \\
\hline
\end{tabular}

: The protein was different with others. This protein be present in some group and not present in other groups after treatment with ethanolic extract of $A$. suberitoides.

: The protein be present

: The protein not present

Description :

I, II, ..., VI : the treatment groups

$\mathrm{a}, \mathrm{b}$ and $\mathrm{c} \quad$ : an individual replication 